\title{
MULTI-STAKEHOLDER COLLABORATION IN URBAN TRANSPORT: STATE-OF-THE-ART AND RESEARCH OPPORTUNITIES
}

\author{
Jesus GONZALEZ-FELIU ${ }^{1 \#}$, Cristina PRONELLO ${ }^{2,3 \#}$, Josep Maria SALANOVA GRAU ${ }^{4 \#^{*}}$ \\ ${ }^{1}$ Saint-Etienne School of Mines, France \\ ${ }^{2}$ Sorbonne University, Paris, France \\ ${ }^{3}$ Polytechnic University of Turin, Italy \\ ${ }^{4}$ Centre for Research and Technology Hellas (CERTH), Thessaloniki, Greece
}

Received 19 July 2018; revised 20 November 2018; accepted 22 November 2018

\begin{abstract}
Transport systems are undergoing a change of paradigm that focuses on resource-sharing and collaboration of multiple and diverse stakeholders. This paper aims to present a state-of-the-art on the main research issues of multistakeholder collaboration in urban transport and address the main contributions of the Special Issue on Collaboration and Urban Transport to the field. To that end, it seems necessary to identify and address the complexity of the relations of the stakeholders in the field, beyond the traditional classification of private and public stakeholders. A functional classification of urban stakeholders related to the different land uses is proposed a refer to space users and space organizers, each with several sub-categories. Furthermore, the collaboration among those stakeholders can take different forms and can be developed at different levels: transactional, informational and decisional. Thus, the main research topics regarding multi-stakeholders' collaboration are defined as: partnerships, resource sharing, resource pooling and Mobility-as-a-Service (MaaS) systems. A set of papers in this special issue focus on Urban Consolidation Centres (UCCs), partnerships in transport under a general perspective, multi-stakeholder cooperation and its barriers, collaborative decision-making, traffic prediction and urban congestion. In the papers, which deal with the field of multi-stakeholder collaboration in urban transport, there is a predominance on the use of surveys, but also a focus on data-driven techniques. As a result, this special issue contributes not only to the theoretical aspects, but adds value to technical and methodological issues.
\end{abstract}

Keywords: collaboration, multi-stakeholder, urban transport, overview, passenger transport, freight transport.

\section{Introduction}

Urban transport systems have strongly evolved in the last years, leading to different paradigms and functional schemes that co-habit in cities. The development of new mobility patterns and the offer of new services - based on resources' sharing - have been proposed in many cities. Most of those schemes derive or can be related to the sharing economy. This is the case of car-sharing and bikesharing systems (both station-based and free-floating), but also the new car rental services among individuals, mixed people-freight transport systems and sharing systems for urban freight transport (as van-sharing, collaborative urban logistics platforms, land and/or lane sharing systems or freight transport pooling initiatives, among others). Numerous solutions have been experimented during recent years around the world. Even if improvements have been observed, various actions highlighted the difficulties for stakeholders to collaborate. Transport is evolving from the concept of enterprise-driven sharing to that of collaboration among private citizens, transforming the traditional unstructured pooling concept in a new form of organised service supported by social media. Consequently, research needs to address the organisational, financial and legal aspects as well as to evaluate the effects of this new approach to mobility on people travel behaviour and on the environment, society and economy. For those reasons, we considered it important to select and present a set of papers dealing with recent researches in the field of multistakeholder collaboration (also known as external or horizontal collaboration) in urban transport.

\footnotetext{
${ }^{*}$ Corresponding author. E-mail: jose@certh.gr

\#Guest Editor of the Special Issue of TRANSPORT on Collaboration and Urban Transport - the manuscript was handled by one of the Associate Editors, who made all decisions related to the manuscript (including the choice of referees and the ultimate decision on the revision and publishing). 
This paper aims at presenting our position as regards to the field of collaboration in urban transport, through an overview of the main works and topics, and analyses the contribution of the selected set of papers to the field of multi-stakeholder collaboration in urban transport. First, an overview of the stakeholders of urban transport and their interactions is given. Then, an overview of the main topics and research subjects regarding collaboration in urban transport is proposed. After that, the main contributions of the set of selected papers, which deal with the field of multi-stakeholder collaboration in urban transport, are analysed. Finally, the main research directions issued from the review are proposed.

\section{The stakeholders of urban transport and their interactions}

To understand the issues and needs of multi-stakeholder collaboration in urban transport, we need to address the complexity of the relations among the stakeholders involved in the field. Several authors address collaboration issues, both in passenger transport (Bulkeley et al. 2011) and in freight transport (Lindholm, Browne 2013; Gonzalez-Feliu 2018). However, also in urban planning collaboration among stakeholders has implication on transport sector (Hall 2014; Carlsson-Kanyama et al. 2008). The majority of authors distinguish the above stakeholders into public and private actors, mainly based on a historical thinking that opposes collective utility (public stakeholders) to business and personal interest (private stakeholders). Another stakeholder analysis framework - the stakeholder theory - is mainly related to private organizations (mainly of commercial nature). However, the current trend shows that the traditional functions of private and public stakeholders are less and less separated and some interventions are nowadays made by both actors. Thus, it seems difficult to adapt the Stakeholder theory to a global urban transport perspective, which is not only a commercial matter but mixes various stakeholders with different aims and goals, not all of them of commercial nature (Nimtrakool et al. 2018), and for which spatial issues are crucial (Gonzalez-Feliu 2018). For those reasons, we propose here to use a functional classification of urban stakeholders related to the different land uses, by extending that of urban freight transport proposed by GonzalezFeliu (2018).

The first category of stakeholders includes the space users, defined as the stakeholders based in the considered area (mainly urban and/or peri-urban) and whose functions have a direct impact on the occupation (static or dynamic) of the space. They can be classified into three categories: generators of transport demand, transport operators, and interface roles and are depicted in Figure 1.

Generators of transport demand are in general stakeholders that induce and generate the demand for transport (Quinet, Vickerman 2004). They are of different nature, have different function in cities and can be classified in the following sub-categories:

- residents in the city who travel having their household location as origin and final destination of most passenger trips (Hensher, Button 2007), but also generate goods trips in terms of shopping trips and home deliveries (Gonzalez-Feliu 2018);

- urban and peri-urban economic activities that attract work, shopping and leisure trips (Ortúzar, Willumsen 2011), but also generate an important part of freight trips (Ogden 1991; Gonzalez-Feliu et al. 2016b). Those activities can be classified in the following subcategories, adapting those of Gonzalez-Feliu (2018): - freight-intensive sectors of B2B nature (i.e. not involving end-consumers making personal shopping

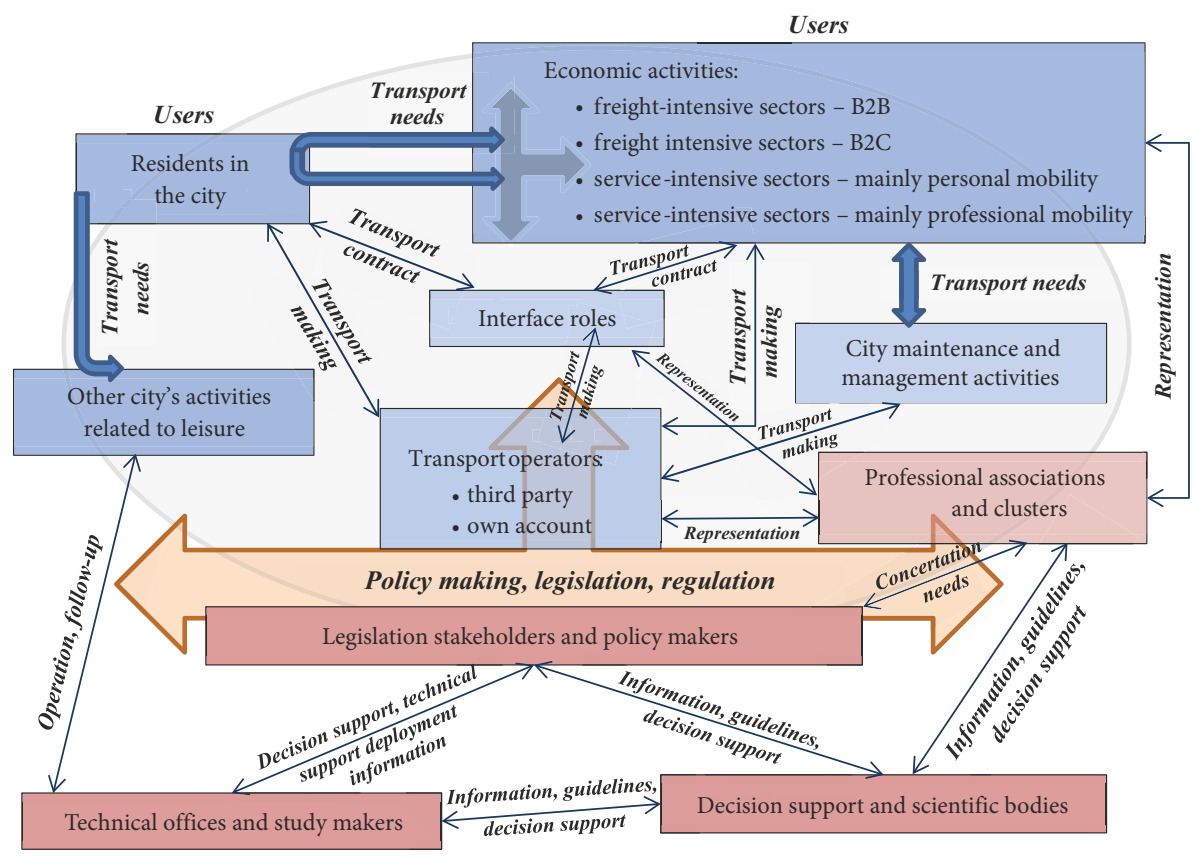

Space consumers

Figure 1. The main stakeholders related to urban transport and their interactions 
trips): agriculture and other primary activities, utilities, construction, manufacturing, wholesaling, transport and logistics;

- freight-intensive sectors of $\mathrm{B} 2 \mathrm{C}$ nature: stores and retailing activities, food and accommodation activities;

- service-intensive sectors involving mainly personal trips, i.e. non-professional: information, finance and insurance, educational services, real estate and rental services, healthcare and social assistance, arts and entertainment, public administrations;

- service-intensive sectors involving mainly professional trips: management services, administrative and support services, waste management, other services;

- public (and private) activities (parks, sports areas, historical monuments, etc.) that can be destination of leisure trips without being linked to an economic activity (Getz 1986; Lue et al. 1993);

- activities related to maintaining and operating the city's life that generate people and goods trips (Segalou et al. 2004): road and network maintenance; household move trips, etc.

Transport operators are the stakeholders that deliver goods. We can find here stakeholders making own-account transport (cities inhabitants making trips with their own vehicle or on foot, or stakeholders carrying freight by their own account) or third party transport providers (public transport stakeholders, taxi and vehicles for hire companies, private bus companies, freight transport operators, etc.).

Interface roles are the stakeholders (public and private) that connect generators of transport demand (transport demand stakeholders) with transport operators.

The second category include the space organizers, whose role is to plan and organize the urban space. They have a direct influence on land and transport planning and reflect the positions of the economic stakeholders within the context of the city. The main subgroups of urban spatial organizers are (extended from Gonzalez-Feliu (2018)):

- public authorities having a legislative role like municipalities, urban communities or regions, among others (including their various technical services). They regulate but also act and deploy transport plans and direct actions that influence transport demand;

- public authorities or private stakeholders (mainly by delegation) with a technical or expert role, but without a legislative role, like urban planning agencies, urban areas, consulting agencies or technical studies actors, among others. They make a technical work mainly related to public decision makers' strategies and act both ex-ante and ex-post with respect to public decisions;

- professional bodies like trade associations, transport federations, chambers of commerce and industry or clusters, among others. They give general advice and can have lobbying/influence function but can also support agreements and consensus;
- decision support roles, research and development activities (public or private) like technical services of transport ministries, energy and sustainable development agencies, research organizations (public or private) or real estate stakeholders, among others. They produce scientific and technical works not directly related to public decisions but the results of those works can help afterwards the decision making of public authorities.

Various authors have analysed the preferences and choices of the above stakeholders (Marchau et al. 2008; Stathopoulos et al. 2012) or their role in the development of urban transport systems (Lindholm, Browne 2013; Lagorio et al. 2015). However, the role of public planners and local authorities traditionally provide the choice and implementation of a solution while the other stakeholders react to those choices and have a more or less generalised acceptance (Spickermann et al. 2014). Even though negotiation and multi-stakeholder decision support methods are proposed (Piantanakulchai, Saengkhao 2003; Loukopoulos, Scholz 2004), there is usually a main stakeholder (mainly a public body) taking decisions and proposing solutions. In collaborative transport, the involved stakeholders are not a number of individuals having different roles but a group with links and relationships, at different decision levels. For those reasons, in the next section we will focus on the different forms of transport-based collaboration among urban stakeholders.

\section{The different forms of stakeholders' collaboration in urban transport: state-of-the-art and current research fields}

According to Gonzalez-Feliu and Morana (2011), collaboration in transport can take different forms and can be developed at different levels: transactional, informational and decisional.

Urban transport, either for passengers or for freight transport, is based on transactions and a contractual basis (Quinet, Vickerman 2004). The first stage of collaboration consists of coordination and standardization of techniques for transactional data exchange. However, transactional collaboration is not always seen as a collaborative practice since standard transactions do not need a high level of collaboration (Mason et al. 2007), although it is mostly considered as the basic condition within which collaboration will not be possible (Gonzalez-Feliu, Morana, 2011). Anyway, the development of standards or unified transactions need in general an ex-ante collaboration among different stakeholders that can be referred to the third level of collaboration (i.e. decisional).

Informational collaboration concerns the mutual exchange of information among different stakeholders (mainly transport carriers, customers, users and public authorities) and it is the most common type of collaboration in urban transport (Pohl 2001). Such an information can be used for organizational issues (optimization-based information exchange), for customers' information (info- 
mobility services) or for service purposes - Mobility-asa-Service (MaaS).

Decisional collaboration concerns the different possibilities of collaboration in transport planning and management (Gonzalez-Feliu et al. 2013b; Muñoz-Villamizar et al. 2017) and can belong to different planning stages (Crainic, Laporte 1997):

- operational planning, i.e. daily operations that can be coordinated or shared;

- tactical planning, middle-term planning stage involving decisions as service network design, routing and scheduling, among others;

- strategic planning related to long term planning decisions such as network design, facility location, finance, commercial strategies and development issues.

Collaboration can also be related to the notion of sharing, intended as "the joint or the alternating use of inherently finite resources, both material and immaterial" but also as "the process of dividing and distributing" (GonzalezFeliu, Morana, 2011). In urban transport, the main shared resources are information, infrastructures and platforms, management/planning tools, vehicles and human resources, etc. In general, resource sharing is a type of decisional collaboration.

Last but not least, collaboration can also be horizontal or vertical (Gonzalez-Feliu et al. 2013b). Horizontal collaboration takes part among stakeholders of same type and level, as for example users, transport providers or shippers. Vertical collaboration takes part among complementary stakeholders of the transport and mobility service value chain. Transactional collaboration is in general vertical, whereas informational can be both vertical and horizontal. In decisional collaboration, both vertical and horizontal collaboration schemes can be seen (Figure 2).

Figure 2 can be completed by exploring more in-depth the collaboration schemes of each level, as for example by addressing the maturity of that collaboration. While for the detailed definition of maturity models we can refer to Potage (1998), the maturity of collaboration can explained through the type and nature of the relations and interactions among the stakeholders involved in that collaboration, under the perspective of group decision (Keeney 2013). In other words, a transport collaboration will be more mature if the group is mature and the collaboration takes part within a systemic viewpoint (GonzalezFeliu et al. 2013b). Transactional collaboration starts by the deployment of peer to peer transaction systems, then define standard, shared and finally integrated transaction systems. This type of collaboration rely on a wide literature and since it is vertical and usually managed by one stakeholder, it remains far from the core of the present issue and will not be examined in-depth in this paper.

Figure 3 depicts the different degrees of maturity in transactional collaboration; for more information on such systems at their different maturity degrees, see Vickrey (1963), Potter and Skinner (2000), Hull (2005), Abrate et al. (2009) or Kamargianni et al. (2016).
Concerning informational and decisional collaboration, since the limits are often difficult to establish, we will examine their maturity as a whole and not separating them. The first degree of such collaboration is that of nonparticipative infomobility services, where users can access to a series of information regarding traffic and infrastructure/transport system status (Urry 2016). A second degree of collaboration is that of MaaS systems, defined as "a mobility distribution model that deliver users' transport needs through a single interface of a service provider. It combines different transport modes to offer a tailored mobility package, like a monthly mobile phone contract. This interpretation encompasses some of the core characteristics of MaaS: customer's need-based, service bundling, cooperativity and interconnectivity in transport modes and service providers" (Jittrapirom et al. 2017). Those systems can be participative or not (i.e. in participative systems users can contribute supplying data to the MaaS system; differently, in non-participative systems the offered service is the only valuable information and the users are only "receptors"). At a bilateral or small group level, informational collaboration can both refer to data sharing, mainly regarding common needs and evolve either into decisional collaboration systems or into participative information sharing systems (i.e. the equivalent of participative MaaS systems but for closed small groups). At the decisional level, the first collaboration degree is that of resource sharing or pooling, which can be related to physical resources (mainly vehicles, platforms or depots), human resources (control workforce, technical workforce, commercial and/ or high management figures, etc.) or know how common processes and techniques. The difference between sharing and pooling is that whereas in sharing systems the resources are alternatively or individually used by each stakeholder, in pooling systems those resources are jointly used by two or more stakeholders. Finally, a more evolved stage of collaboration is that of "organisational collaboration", i.e. that of making joint organisational schemes such as mixing routes or logistics schemes, even merging them (Pan et al. 2013), and having a joint planning and management vision (Figure 4).

From the above types of collaboration, and according to the recent literature, we can identify the main research topics regarding multi-stakeholders' collaboration. The subsections below do not represent an exhaustive review of current research but allow proposing a general overview. Anyway, four main subjects of collaboration are dominant in literature: partnerships (which are in general a form of organizational collaboration), resource sharing, resource pooling and MaaS systems.

\subsection{Partnerships}

Partnerships are one of the main issues regarding policies and actions about sustainable urban transport (Goldman, Gorham, 2006). The research regarding partnerships and agreements among different stakeholders has been developed for decades in both personal mobility (not only at 


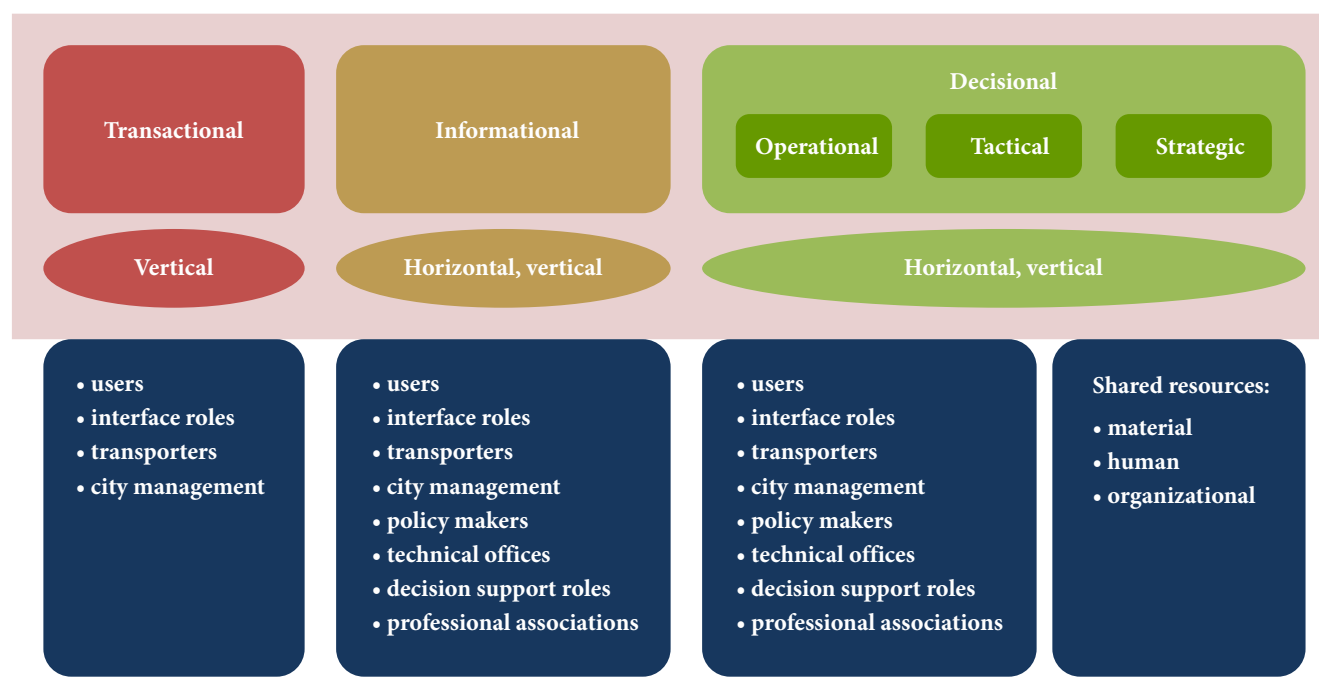

Figure 2. Types of collaboration and their links to urban transport planning

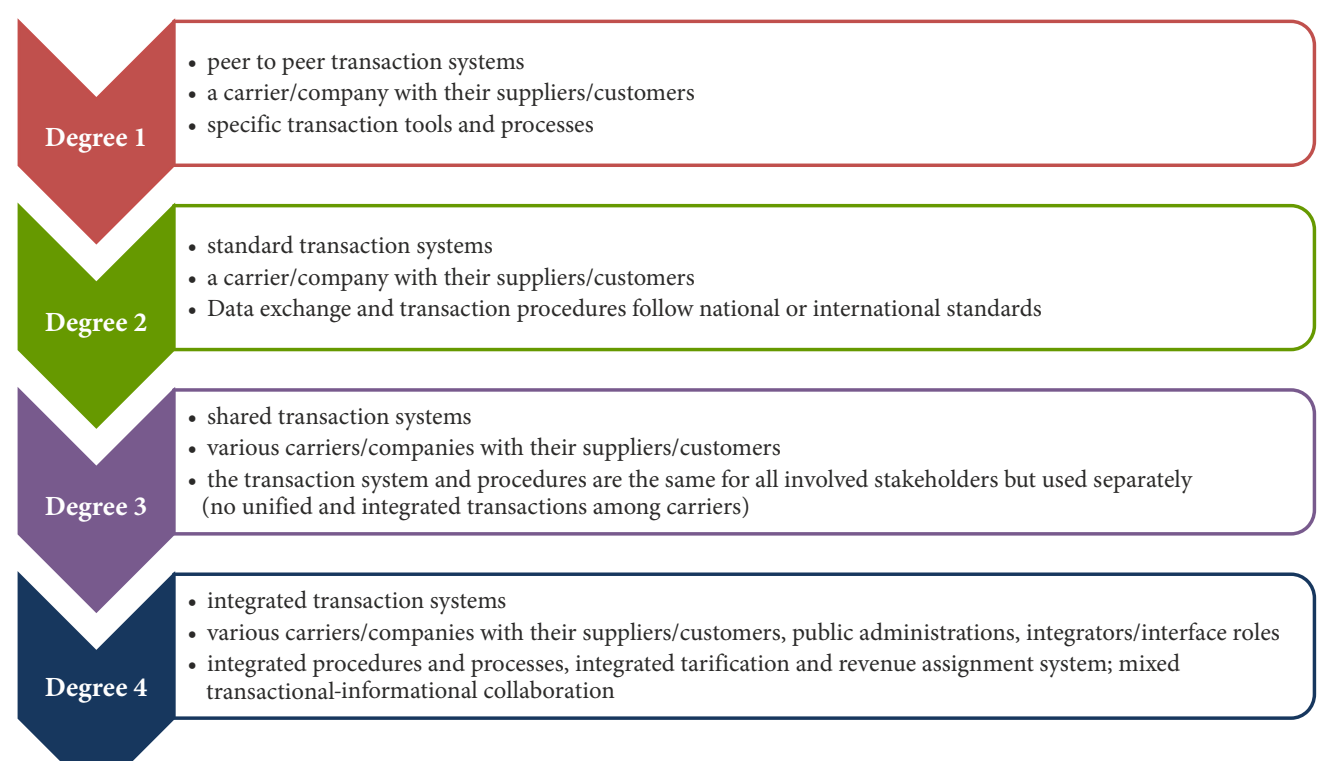

Figure3. The different degrees of maturity in transactional collaboration

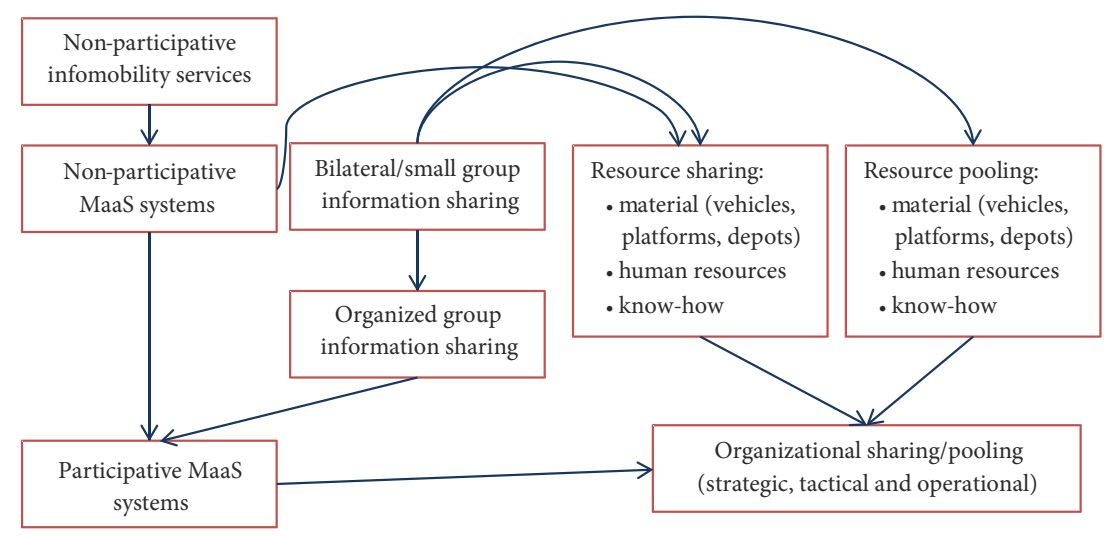

Figure 4 . The different degrees of maturity in informational and decisional collaboration 
urban level, but also at inter-urban one, Glaister (1999)) and logistics (Lambert et al. 1999, 2004). Although various terms are used, the dominant issue is that of public-private partnerships (PPP), a term used initially for investment and financing purposes in various fields but often associated to urban planning and development (Brooks et al. 1984; Endicott 1993; Bailey 1994). PPP has evolved to a more broad vision (Boyle 1989) and nowadays accepts two definitions (Browne et al. 2004):

- narrow PPPs refer to financial agreements and cooperation between public and private stakeholders, in order to provide funds for the development of public projects when public budgets do not allow to entirely funding the project. They consider different options such as the introduction of private sector ownership into state-owned businesses (via a full range of possible juridical and administrative structures) or finance projects and arrangements including concessions and franchises; they also state the use and refunding strategy of the resulting infrastructure of service to allow private investors refunding their invested capital;

- broad PPPs are related to non-contractual cooperation, or non-juridical agreements between public and private stakeholders, and concern other fields than finance. They can take various forms, like the involvement of the public sector's intervention into private practices and operations, consultation and dialogue in public decision-making, or operational actions coordination and cooperation, among others.

The differences between narrow and broad PPPs are shown in Table 1. More information about the difference between narrow and broad PPPs can be found, respectively, in Koppenjan, Enserink (2009); Yescombe, Farquharson (2018) and in Browne et al. (2004).
A rich literature, mainly related to economic and financial issues, refers to narrow PPPs (Osborne 2002) whose a main subject is risk sharing and management strategies (Akintoye, Beck 2009) ${ }^{1}$, mainly related to quantitative methods to manage and assess risk allocation (Grimsey, Lewis 2002; Abednego, Ogunlana 2006; Medda 2007; Chung et al. 2010). Another important subject concerning quantitative methods is performance assessment and return on investment of PPPs (Gonzalez-Feliu et al. 2013a). Evidence-based studies are also popular in research regarding narrow PPPs, mainly to identify the main developments levers and limits in a country-based context (Koppenjan 2005; De Jong et al. 2010; Willoughby 2013) or to address contractual and efficiency issues (Pina, Torres 2006; Roy, Yvrande-Billon 2007; Haughton, McManus 2012). Although research is mainly related to transport infrastructures, some researches deal specifically with urban transport systems (Pina, Torres 2006) or with goods deliveries systems (Gonzalez-Feliu et al. 2013a, 2013b).

Broad PPPs are more difficult to identify, since they are not always considered as PPPs but other types of publicprivate collaboration (Boyle 1989). However, several seminal works address those types of partnerships in a clearly identifiable way. Main research in terms of broad PPPs is qualitative and deals with stakeholders' relations and levers/limitations to the development of those partnerships (Carley 2000; Browne et al. 2004; Davison, Knowles 2006; Tight et al. 2011; Hine, Mitchell 2017). We observe a particular case - Freight Quality Partnerships - representing the agreement between public authorities and transport operators to improve the quality of urban deliveries (similarly defined to bus quality partnerships; Davison, Knowles (2006)), popular subject of research in the last years (Browne et al. 2004; Cherrett et al. 2012; Ballantyne et al. 2013; Taniguchi, Thompson 2014).

Table 1. Differences between narrow and broad PPPs (based on Browne et al. 2004)

\begin{tabular}{|l|l|l|}
\hline & \multicolumn{1}{|c|}{ Narrow PPPs } & \multicolumn{1}{|c|}{ Broad PPPs } \\
\hline $\begin{array}{l}\text { Contractual } \\
\text { issues }\end{array}$ & $\begin{array}{l}\text { Formalised co-operation in a joint venture or other } \\
\text { juridical forms }\end{array}$ & $\begin{array}{l}\text { Relationship between partners is } \\
\text { only partly formalized or not at all } \\
\text { formalized }\end{array}$ \\
\hline $\begin{array}{l}\text { Resource } \\
\text { sharing }\end{array}$ & $\begin{array}{l}\text { Resources made available by both } \\
\text { partners put at disposal of the stakeholder (existing } \\
\text { or new) that carries out the project }\end{array}$ & $\begin{array}{l}\text { Partners retain control of the resources they provide. } \\
\text { In most cases, there is not financial sharing but mainly } \\
\text { human and informational }\end{array}$ \\
\hline $\begin{array}{l}\text { Risk and reward } \\
\text { sharing }\end{array}$ & Yes & No \\
\hline $\begin{array}{l}\text { Coordination } \\
\text { and governance }\end{array}$ & $\begin{array}{l}\text { Coordination between the stakeholder that carries } \\
\text { out the project and its governance instances }\end{array}$ & $\begin{array}{l}\text { Coordination through network structures or agreement } \\
\text { instances }\end{array}$ \\
\hline $\begin{array}{l}\text { Application } \\
\text { issues }\end{array}$ & $\begin{array}{l}\text { Mainly related to the development of } \\
\text { infrastructures or transport systems developed } \\
\text { in a long term refunding base }\end{array}$ & $\begin{array}{l}\text { Mainly related to planning, pilot and test issues or to } \\
\text { short-middle terms initiatives separately funded by one } \\
\text { or more stakeholders }\end{array}$ \\
\hline $\begin{array}{l}\text { Types of projects } \\
\text { and examples }\end{array}$ & $\begin{array}{l}\text { Highways, railway infrastructures, bus-based } \\
\text { transport systems, car-sharing/bike-sharing systems, } \\
\text { urban freight platforms, etc. }\end{array}$ & $\begin{array}{l}\text { Info-mobility, intelligent transport systems and } \\
\text { other information sharing initiatives, freight quality } \\
\text { partnerships, good practice charts, etc. }\end{array}$ \\
\hline
\end{tabular}

\footnotetext{
$\overline{1}$ The list of works presented here is not exhaustive but shows a representative set of the field, focusing mainly on research addressing PPPs for urban transport projects (personal mobility, passenger and/or goods transport).
} 


\subsection{Vehicle sharing systems}

Pooling and sharing actions are the result of decisional collaboration but they need strategic collaboration to be developed, tactical collaboration to ensure their planning and continuity and operational collaboration to address their daily functions (Belk 2014). Since the idea of this paper is not to distinguish mobility from freight transport, we present here the case of vehicle sharing, i.e. the use of a same vehicle fleet by different users/companies, but the use being individual; two users/companies will not share the vehicle at the same time but the system is organized to allow each individual using the vehicle in different periods. More precisely, we can define a vehicle sharing systems a model of vehicle rental for short time periods, the hour (or the half hour) being often the basis of the location. Although very popular in the last years, the first systems (mainly for car-sharing) are found in the 1970's (Shaheen et al. 1998). To propose a typology of such systems, it is important to examine three main elements: the type of vehicle being shared, the owner of the vehicle and the place where the vehicle is taken and returned.

Concerning vehicles, the three most known systems are bike-sharing (Millard-Ball et al. 2005), car-sharing (Katzev 2003) and freight vehicle sharing, mainly vans or small trucks (SUGAR 2011). Regarding ownership, we observe private systems (owned by a private stakeholder), public (or private-public) systems and peer-to-peer systems, where individuals offer their own vehicles during limited time slots. Finally, regarding taking/returning the vehicle, we consider:

- station-based systems, presenting two variants:

a) fixed station-based systems, obliging the user to bring the vehicle to the station where it was picked up;

b) non-fixed station-based systems, needing the vehicle to be left in a station but not necessarily in the same one where it was picked up;

- free floating systems: the vehicle is left in any free parking place in the city and the availability of vehicles as well as the exact location of vehicles are checked through specific applications or websites.

According to the above classification, we can propose the typologies of vehicle sharing systems reported in Table 2.
Concerning bike-sharing systems, the main research topics refer to:

- station location (García-Palomares et al. 2012; Chen et al. 2015; Frade, Ribeiro 2015);

- bike repositioning/equilibration schemes, mainly in an inventory optimization perspective (Caggiani, Ottomanelli 2012; Chemla et al. 2013; Raviv, Kolka 2013; Raviv et al. 2013; Schuijbroek et al. 2017);

- demand assessment and transport behaviour analysis (Fricker et al. 2012; Tang et al. 2011; Tran et al. 2015).

Moreover, with the development of big and open data strategies, issues regarding smart bike-sharing and data production and analysis in bike-sharing planning are starting to be addressed (Midgley 2009; Vogel et al. 2011). Socio-economic issues like acceptance and incentives are also analysed in the literature (Fricker, Gast 2016). Finally, evaluation and assessment of flows induced by bikesharing systems seems to be an important research topic, although not well developed yet (Nair et al. 2013).

Car-sharing has been paid a high attention by the scientific community (Steininger et al. 1996; Katzev 2003). An important set of works involves optimization issues (Brandstätter et al. 2016), like network design and station/depot location and development (e.g. strategic and tactical planning: De Almeida Correia, Antunes (2012), Rickenberg et al. (2013), Boyac1 et al. (2015)) or relocation and balancing issues (e.g. operational planning: Fan et al. (2008), Kek et al. (2009); Repoux et al. (2015)). Both bike-sharing and car-sharing systems have been studied by the optimization and operations research communities as they introduce new organizational and planning models. Another important field, common also to bike-sharing, is demand estimation and consumers' behaviour (Meijkamp 1998; Catalano et al. 2008), although the main economic issues related to car-sharing are focused on consumption and market issues; such issues are mainly related to the development of the economic model of car-sharing systems (Cervero 2003; Shaheen et al. 2006; Bardhi, Eckhardt 2012; Shaheen, Cohen 2013) or to the use of households' resources (Martin et al. 2010). Empirical studies exist but are less developed than for bike-sharing systems (Meijkamp 1998; Shaheen et al. 2004). Finally evaluation and

Table 2. Main types of vehicle sharing systems

\begin{tabular}{|l|l|l|l|}
\hline \multirow{2}{*}{ Type of vehicle } & \multicolumn{1}{c|}{$\begin{array}{c}\text { Professional vehicle sharing } \\
\text { (public, private, mixed) }\end{array}$} & \multicolumn{1}{c|}{ Peer-to-peer vehicle sharing } \\
\cline { 2 - 4 } & \multicolumn{1}{|c|}{ Station-based } & \multicolumn{1}{c|}{$\begin{array}{c}\text { Free floating } \\
\text { (no known station-based systems) }\end{array}$} \\
\hline $\begin{array}{l}\text { Bike-sharing (DeMaio 2009; } \\
\text { Larsen 2013) or ride-sharing } \\
\text { (Agatz et al. 2012) }\end{array}$ & $\begin{array}{l}\text { Non-fixed station } \\
\text { (mechanical or electric bikes) }\end{array}$ & $\begin{array}{l}\text { Free floating systems } \\
\text { (mechanical bikes) }\end{array}$ & n.a. \\
\hline $\begin{array}{l}\text { Car-sharing (Mingrone et al. } \\
\text { 2015) }\end{array}$ & $\begin{array}{l}\text { Fixed station } \\
\text { Non-fixed station }\end{array}$ & $\begin{array}{l}\text { Free floating systems } \\
\text { (thermic vehicles) }\end{array}$ & Peer-to-peer car-sharing \\
\hline Freight transport sharing & $\begin{array}{l}\text { Fixed station van-sharing } \\
\text { (SUGAR 2011) }\end{array}$ & n.a. & n.a. \\
\hline Mixed systems (car/freight) & $\begin{array}{l}\text { Fixed station-based systems having } \\
\text { private cars and freight vehicles }\end{array}$ & n.a. & Peer-to-peer car/van-sharing \\
\hline
\end{tabular}


assessment of sharing services have been carried out for both economic and environmental issues (Fellows, Pitfield 2000; Lane 2005; Awasthi, Chauhan 2011; Martin, Shaheen 2011a, 2011b).

Finally, little research explicitly deals with freight vehicle sharing and it remains mainly descriptive (Trentini, Mahléné 2010; SUGAR 2011; Gonzalez-Feliu, Morana 2011; Bubel, Szymczyk 2016), although a first assessment of impacts of freight vehicle sharing in the environment has also been made (Andriankaja et al. 2015).

\subsection{Transport pooling approaches}

Transport pooling can be seen as the joint use of a vehicle, simultaneously, by two or more individuals, and can be defined "resource pooling" (Gonzalez-Feliu, Morana 2011). In urban transport, we observe two main transport pooling phenomena: carpooling made for personal mobility and logistics pooling for freight transport. The notion of logistics pooling is broader and does not only involve transport means, but also other stages of the logistics chain (Gonzalez-Feliu, Morana 2011). Therefore, we precise that the "logistics pooling" presented here concerns freight transport and the directly related logistics operations (i.e. since pooling will increase the number of intermediate reloading, crossdocking and consolidation operations will be carried out).

The research on carpooling focuses mainly on optimization issues, mainly related to the assignment of potential users to vehicles (Baldacci et al. 2004; Calvo et al. 2004; Ferrari et al. 2003; Yan et al. 2011) or to the information system functionalities related to the assignment system (Ferreira et al. 2009; Trasarti et al. 2012; Dimitrakopoulos et al. 2012). Socio-economic issues remain less studied at the time being, despite the pioneer work of Sagner (1974).

Research on urban logistics pooling is recent and proposes pooling systems as an alternative to classical Urban Consolidation Centres (UCCs) (Verlinde et al. 2012; Morana et al. 2014). Indeed, urban consolidation in its classical form has been appointed to be not always efficient and presents various limits that can be overcome via alternative consolidation and collaboration strategies (Verlinde et al. 2012). We consider freight transport pooling as the identification and use of residual capacities of an already planned vehicle to include more goods, not coming from a classical customer but from another transport carrier (that will not activate a vehicle for that) or from a "freight transport pooling platform". The idea has been widely developed in France and Europe for interurban transport (Simonot, Roure 2007) but is now being applied to urban freight transport (Gonzalez-Feliu, Morana 2011; Gonzalez-Feliu, Salanova 2012; Morana et al. 2014). Main researches on that field concern optimization issues, mainly vehicle routing and re-routing (GonzalezFeliu, Salanova 2012; Thompson, Hassall 2012; GonzalezFeliu, Salanova Grau 2015; Muñoz-Villamizar et al. 2015, 2017; Eitzen et al. 2017) or supply chain planning (Ballot, Fontane 2010), and evidence-based studies of collabora- tion deployment, incentives and limitations (Gevaers et al. 2011; Gonzalez-Feliu, Morana 2010, 2011, 2014; Verlinde et al. 2012; Morana et al. 2014). Finally, impact and performance assessment start to be considered in specific researches about assessment and evaluation of urban freight transport pooling (Gonzalez-Feliu, Morana 2014; Morana, Gonzalez-Feliu 2015).

\subsection{The emerging field of Mobility-as-a-Service (MaaS)}

As said above, one of the first forms of collaboration is based on information exchange. Although information exchange and info-mobility is widely observed in urban transport, an emerging field based on that informational collaboration -MaaS - is currently growing (Goodall et al. 2017). MaaS can be defined as the proposal, by a specialized operator, of monthly mobility packages (i.e. the real time information and its processed results that support the decision of taking the most convenient combination of transport modes to make a trip, on the basis of a monthly package). The concept was proposed by Hietanen (2014), although several other similar mobility packages were already being studied at research level (Grotenhuis et al. 2007; Li et al. 2010; Pronello et al. 2017). MaaS does not limit its scope to public transport or to private car route selection (as classical info-mobility systems), but it aims at including every possible transport mean from public transport to taxis and rental cars, in order to have an overall vision of urban mobility and propose the most suitable transport mean to each user.

MaaS puts in the middle of mobility a new stakeholder - a new mobility operator acting as service enabler through a platform - which gives information about the most convenient transport modes, manages the ticketing issues and the costs. The MaaS business model is based on the valorisation of the information related to traffic conditions, public transport operations and private transport schemes (mainly taxis). The added-value is the set of data allowing a user deciding the most suitable transport mode (or a combination of modes) to make the trip in a very short time period.

The MaaS is still in its infancy and after the exploratory research setting the concept and the ideas (Hietanen 2014; Sochor et al. 2015) some researchers are starting to explore the potential of sustainability of MaaS and how it can be implemented and deployed in cities (Pronello et al. 2016; Expósito-Izquierdo et al. 2017; Goodall et al. 2017; Jittrapirom et al. 2017). Although the field is emerging, the research seems to grow quickly.

However, MaaS can change several collaboration paradigms, mainly in its participative version. Indeed, participative MaaS systems involve various stakeholders providing information and/or processed data, and need specific processes and management systems. Indeed, those systems do not follow a centralized decision and management paradigm but need a group and collaborative approach (Keeney 2013). Moreover, MaaS in general are based on 
providing services from and with transport and mobility information, so they are at the frontier between informational and decisional collaboration. Optimization and decision support systems can then be integrated to decision processes, and the collaboration becomes more and more interactive. Moreover, the user's choices and habits can then be used to support planning and development issues related to the whole urban mobility system, so finally MaaS adds a data-driven, dynamic and group dimension to collaboration, making it more systemic and integrated.

Finally, the four main research subjects presented here regarding multi-stakeholder collaboration in urban transport are complementary, and can be included into a more complex, systemic approach, that of "integrated urban collaborative mobility systems". Those systems would consider both passenger and goods transport flows, the various modes that are available in urban zones, as well as the related infrastructures, organization, demand needs and supply options. The trend given by those four subjects sees urban mobility as an interconnected system that needs to be examined first in its overall form, then, to enter more in detail on its processes, decomposed.

\section{Contribution of the set of papers to the multi- stakeholder collaboration in urban transport and new research directions}

The aim of assembling a set of papers was to propose a systematic vision of sharing economies and resource pooling in urban transport, including both people and freight transport. Topics of interest were mainly focused on the planning, design, management and evaluation of urban transport systems (involving people and/or freight) in the context of collaboration described above.

Finally, a set of papers in the field of multi-stakeholder and collaboration in urban transport have been selected as having both the quality required and the relevance/pertinence as regards to the selected topic. Most papers deal with freight transport, showing that the term "collaborative transport" is more often associated to freight than to passenger transport. However, researches dealing with passenger transport or mobility management including both passengers and goods are also present. Indeed, some of the papers explicitly deal with freight transport, two regarding only people mobility and one including both people and goods transport.

The other part of the papers deals with the subject of UCCs but under different perspectives and points of view. It is important to observe that UCCs are not transport pooling systems since they do not refer to a resource sharing or pooling but are a particular form of logistics service provider in which some variants involve public and private stakeholders and imply agreements and collaboration to make UCCs operational and viable along the time (Allen et al. 2014; Gonzalez-Feliu et al. 2014). The contribution of each paper is different, and aims at completing existing literature in different points:
- one the most difficult issues refers to users' (and citizens') perception and acceptance of urban logistics systems and, more precisely, of UCCs (Gonzalez-Feliu, Morana 2011; Nimtrakool et al. 2018; GonzalezFeliu, Malhéné 2014). Paddeu et al. (2018) complete the recent research of Nimtrakool et al. (2018), focused on barriers of innovation, by introducing a multi-stakeholder dimension and a survey-based analysis; the aim is exploring the main drivers and barriers to the implementation of UCCs on a collaborative basis (and then involving different stakeholders). Results confirm those of previous two researches and show that the barriers to the implementation of UCCs have been little studied but a body of research is starting to set the guidelines to explore that field;

- another important issue related to UCCs deployment is related to impact assessment, since it is important to examine the potential impacts of UCCs, in an exante perspective, to feed the discussion about the potential deployment of those UCCs. A few of the papers deal with the estimation of those impacts. Although some works deal with estimation (Muñuzuri et al. 2018; Gonzalez-Feliu, Morana 2010; Vaghi, Percoco 2011; Andriankaja et al. 2015), most of them are based on ex-post evaluations, and are mainly environment-based (only Muñuzuri et al. (2018) and, more recently, Faure et al. (2016) and Nimtrakool et al. (2018) address explicitly monetary issues). Estrada et al. (2018) introduce a modelling approach to estimate the costs and impacts of various scenarios, including a UCC, night deliveries with current delivery schemes and a combination of both, showing which is the contribution of each solution (UCCs and night deliveries) and their respective cost. Veličković et al. (2018) make also an impact assessment but including external costs;

- concerning the economic evaluation, the identification and assessment of external costs is a little studied topic in urban logistics (Melo, Costa 2011) but remains more developed in mobility (Verhoef 1994; Mayeres et al. 1996; Maibach et al. 2008). De Langhe (2017) and Cárdenas et al. (2017) made a first contribution to the definition of urban transport external costs, respectively for freight tramways (which are a form of urban consolidation) and B2C deliveries. However, their research is based on the identification of costs and the methods of quantification for existing systems, and not deal with ex-ante assessment. Veličković et al. (2018) focus on external costs of urban freight transport and apply it to UCCs scenarios, showing how the inclusion of those costs can lead to different decisions in the choice of the urban consolidation strategy of a city or urban zone;

- a largely explored field in urban logistics is policy making (Lindholm, Browne 2013). However, the definition and formalization of perspectives of development remain very local and it is difficult to propose 
them at national or international level on a standard basis. To deal with that gap, Van Duin et al. (2018) focus on how using the Q-methodology to identify and select perspectives on urban freight policies. Although the paper proposes a general methodology applied to urban freight transport, the authors apply it to the deployment of UCCs under a Dutch perspective (and, thus, a national context).

All of the above mentioned papers contribute to the state-of-the-art on decision support related to partnerships and agreements around UCCs. Other papers of the selected set contribute to the literature regarding partnerships, under a more general perspective. Muñuzuri et al. (2018) focus on multi-stakeholder cooperation in the definition of common objectives and freight systems, so under a broad partnership perspective. To analyse such a collaboration, a survey-based methodology is proposed, and results show the main reactions of stakeholders to various alternatives to deliver the Seville central marketplace. Then, the stakeholders' acceptance of possible scenarios of development is assessed and theoretical research on stakeholders' choice in urban logistics (Stathopoulos et al. 2012) is proposed by explicitly addressing the issues of cooperation (and considering there is an individual and a group component) but also by providing practical but generalizable results. Liu et al. (2018) address the issue of acceptance of congestion-pricing policies in Melbourne, Australia. Using a survey-based analysis, authors show the acceptance of inhabitants as regards to different congestion pricing policies, in relation to different users' profiles. This contribution can feed the discussion among public and private stakeholders to deploy broad partnerships based on congestion-pricing policies.
Table 3 summarises the main contributions of the selected set of papers from the Special Issue on Collaboration and Urban Transport, which deal with the field of multistakeholder and collaboration in urban transport.

Concerning methodology, we observed that in a larger part of the selected set of papers a predominance of survey-based and data-driven techniques (selected papers are based on surveys and data collection techniques, both quantitative and qualitative, and other two involve datadriven algorithms and computer science tools). A smaller part of the selected set of papers are related to modelling techniques and they all refer to economic issues (two on costs and the third on congestion impacts, then producing data and indicators to evaluate the concerned collaborative transport systems). In general, the contribution of the Special Issue on Collaboration and Urban Transport to the literature is not only related to the technical issues of collaboration, but contributes to the methodological approach, related to data production in the research design and to the models/methods, showing the importance of data-driven approaches in decision support (GonzalezFeliu et al. 2016a).

The Special Issue on Collaboration and Urban Transport allowed us to examine emerging research areas, both thematic and methodological, in collaboration and sharing economies regarding urban transport. According to the selected set of papers, which deal with the field of multistakeholder and collaboration in urban transport, it seems that partnerships and agreements, as well as stakeholders' interactions, is a topic that, even if it is worth of investigation, is still in search of standards and dominants. Although the present Issue proposes some advances in the analysis of stakeholders' needs and attitudes towards

Table 3. Summary of the main topics and contributions of the set of papers, selected from the Special Issue on Collaboration and Urban Transport, which deal with the field of multi-stakeholder and collaboration in urban transport

\begin{tabular}{|l|l|l|l|l|}
\hline \multicolumn{1}{|c|}{ Authors } & Type of transport & Collaboration type & \multicolumn{1}{|c|}{ Main methods } & Main contribution \\
\hline $\begin{array}{l}\text { Van Duin } \\
\text { et al. } \text { (2018) }\end{array}$ & Goods transport & $\begin{array}{l}\text { Decisional - } \\
\text { partnerships }\end{array}$ & Survey & $\begin{array}{l}\text { Introduce the Q-methodology to identify } \\
\text { perspectives of collaboration }\end{array}$ \\
\hline $\begin{array}{l}\text { Muñuzuri } \\
\text { et al. }(2018)\end{array}$ & Goods transport & $\begin{array}{l}\text { Decisional - } \\
\text { partnerships }\end{array}$ & Survey & $\begin{array}{l}\text { Address conditions of collaboration by various } \\
\text { stakeholders }\end{array}$ \\
\hline $\begin{array}{l}\text { Golini } \text { et al. } \\
(2018)\end{array}$ & Goods transport & $\begin{array}{l}\text { Informational - } \\
\text { MaaS }\end{array}$ & $\begin{array}{l}\text { GIS-based DSS/ } \\
\text { data-driven approach }\end{array}$ & $\begin{array}{l}\text { Propose a decision support tool to pre-process and } \\
\text { produce data for collaborative decision making }\end{array}$ \\
\hline $\begin{array}{l}\text { Liu } \text { et al. } \\
(2018)\end{array}$ & $\begin{array}{l}\text { Passenger } \\
\text { transport }\end{array}$ & $\begin{array}{l}\text { Decisional - } \\
\text { partnerships }\end{array}$ & Survey & $\begin{array}{l}\text { Address the issues of acceptance of congestion- } \\
\text { pricing }\end{array}$ \\
\hline $\begin{array}{l}\text { Paddeu } \text { et al. } \\
(2018)\end{array}$ & Goods transport & $\begin{array}{l}\text { Decisional - } \\
\text { partnerships }\end{array}$ & Survey & Address the barriers of collaboration \\
\hline $\begin{array}{l}\text { Estrada } \text { et al. } \\
(2018)\end{array}$ & Goods transport & $\begin{array}{l}\text { Decisional - } \\
\text { partnerships }\end{array}$ & Modelling & $\begin{array}{l}\text { Assess the impacts of UCCs thanks to a cost } \\
\text { estimation model }\end{array}$ \\
\hline $\begin{array}{l}\text { Veličković } \\
\text { et al. }(2018)\end{array}$ & Goods transport & $\begin{array}{l}\text { Decisional - } \\
\text { partnerships }\end{array}$ & Modelling & $\begin{array}{l}\text { Assess the impacts of UCCs introducing external } \\
\text { cost analysis }\end{array}$ \\
\hline $\begin{array}{l}\text { Tettamanti } \\
\text { et al. }(2018)\end{array}$ & Overall traffic & $\begin{array}{l}\text { Informational - } \\
\text { MaaS }\end{array}$ & $\begin{array}{l}\text { Prediction algorithm/ } \\
\text { data driven approach }\end{array}$ & $\begin{array}{l}\text { Propose a traffic prediction algorithm for short } \\
\text { term horizons handling incomplete data sets }\end{array}$ \\
\hline $\begin{array}{l}\text { Maciejewski, } \\
\text { Bischoff } \\
(2018)\end{array}$ & $\begin{array}{l}\text { Passenger } \\
\text { transport }\end{array}$ & $\begin{array}{l}\text { Decisional - } \\
\text { vehicle sharing }\end{array}$ & Modelling & $\begin{array}{l}\text { Evaluate the impacts of autonomous taxi } \\
\text { generalization in urban congestion }\end{array}$ \\
\hline
\end{tabular}


collaboration in urban transport, the field needs more indepth research on the collaborative/group aspects of partnerships and agreements, on the stakeholders' needs and on the analysis of their acceptance/will to collaborate. The selected set of papers shows that data-driven approach, mainly survey-based, can be systematized and promoted to go towards a standard. Data production and data visualization can also help to support collaboration.

Another important topic is related to data services, info-mobility and MaaS in the sharing economies. The field is emerging, and the collaborative issues remain still under examined. Research in the valorisation/monetarization of data services, confidentiality issues, conflicts and relations among users, but also assessment and evaluation of impacts related to those services seem to be an emerging set of knowledge in this field.

A further research direction is related to group decision support. Although several researches are dealing with multi-stakeholder decision support (Gonzalez-Feliu et al. 2013b; Macharis et al. 2014), they consider stakeholders as individuals influencing the final decision but not as a group having the same interest and aiming at defining a consensual solution (Raiffa et al. 2007; Gonzalez-Feliu, Morana 2011). Decision support methods not focused on a final single decision maker (either taking into account multiple stakeholders' advices or not) but group-oriented, as well as common approaches applied to urban transport seem to be challenging topics that have a high expectation.

Finally, the integration of both mobility and urban freight transport remain little explored. In collaborative transport and in cooperation among stakeholders, it seems important to integrate the stakeholders and flows that share the same infrastructures. Although research starts to deal with common traffic assessments or flow estimations, the field remains little examined. Research on joint flow modelling and assessment related to integrated people and freight transport systems, or evaluation of impacts of collaborative transport on overall traffic (including private transport, public transport and deliveries) seem to be important not only for the research but also for practical issues. Last but not least, accessibility analyses integrating passengers and freight flows are one of the most challenging urban transport topics for the next years (Van Wee 2016) and merit a particular interest of researchers and practitioners.

\section{Conclusions}

This paper proposed an analysis and overview on the of the set of papers, selected from the Special Issue on Collaboration and Urban Transport, which are dealing with the field of multi-stakeholder and collaboration in urban transport. Collaboration is a complex subject that can take different forms and the scientific literature has examined it in different ways referring to urban transport. Freight transport uses more explicitly the term "collaborative" since in passengers' mobility the main term used is related to "sharing" or "pooling". Another important topic is that of agreements and partnerships. However, the importance of data production and MaaS approaches is increasing.

The main contributions of the selected set of papers from the Special Issue on Collaboration and Urban Transport deal with bringing a more unified context to analyse partnerships and collaborations, introduce the importance of economic assessment when examining the impacts of transport collaboration and are all directly related to data production and analysis, showing that data-driven approaches are necessary to decrease the gap that still exists between research and practice in urban transport collaboration.

From the proposed research directions, we can conclude that the topic of collaboration is still at an emerging stage, and will be developed more in-depth, mainly related to the informational collaboration (and MaaS approaches) but also to the capability of decision support methods to address the multi-stakeholder and group features of collaboration.

\section{Acknowledgements}

The research field on the multi-stakeholder collaboration in urban transport has been proposed following a collaboration between the Young Researcher Initiative "Horrea" in urban Logistics of the Institute of Urban Transport and Mobility (Saint-Etienne, France), the research chair "Intelligent Mobility and Urban Dynamics" (Paris, France) and the Hellenic Institute of Transport - CERTH (Thessaloniki, Greece).

\section{References}

Abednego, M. P.; Ogunlana, S. O. 2006. Good project governance for proper risk allocation in public - private partnerships in Indonesia, International Journal of Project Management 24(7): 622-634. https://doi.org/10.1016/j.ijproman.2006.07.010

Abrate, G.; Piacenza, M.; Vannoni, D. 2009. The impact of integrated tariff systems on public transport demand: evidence from Italy, Regional Science and Urban Economics 39(2): 120-127. https://doi.org/10.1016/j.regsciurbeco.2008.05.014

Agatz, N.; Erera, A.; Savelsbergh, M.; Wang, X. 2012. Optimization for dynamic ride-sharing: a review, European Journal of Operational Research 223(2): 295-303.

https://doi.org/10.1016/j.ejor.2012.05.028

Akintoye, A.; Beck, M. 2009. Policy, Finance and Management for Public-Private Partnerships. Blackwell Publishing Ltd. 469 p. https://doi.org/10.1002/9781444301427

Allen, J.; Browne, M.; Woodburn, A.; Leonardi, J. 2014. A review of urban consolidation centres in the supply chain based on a case study approach, Supply Chain Forum: an International Journal 15(4): 100-112.

https://doi.org/10.1080/16258312.2014.11517361

Andriankaja, D.; Gondran, N.; Gonzalez-Feliu, J. 2015. Assessing the environmental impacts of different IPSS deployment scenarios for the light commercial vehicle industry, Procedia CIRP 30: 281-286.

https://doi.org/10.1016/j.procir.2015.02.159

Awasthi, A.; Chauhan, S. S. 2011. Using AHP and DempsterShafer theory for evaluating sustainable transport solutions, Environmental Modelling \& Software 26(6): 787-796. https://doi.org/10.1016/j.envsoft.2010.11.010 
Bailey, N. 1994. Towards a research agenda for public-private partnership in the 1990s, Local Economy: the Journal of the Local Economy Policy Unit 8(4): 292-306.

https://doi.org/10.1080/02690949408726205

Baldacci, R.; Maniezzo, V.; Mingozzi, A. 2004. An exact method for the car pooling problem based on Lagrangean column generation, Operations Research 52(3): 422-439.

https://doi.org/10.1287/opre.1030.0106

Ballantyne, E. E. F.; Lindholm, M.; Whiteing, A. 2013. A comparative study of urban freight transport planning: addressing stakeholder needs, Journal of Transport Geography 32: 93-101. https://doi.org/10.1016/j.jtrangeo.2013.08.013

Ballot, E.; Fontane, F. 2010. Reducing transportation $\mathrm{CO}_{2}$ emissions through pooling of supply networks: perspectives from a case study in French retail chains, Production Planning \& Control: The Management of Operations 21(6): 640-650. https://doi.org/10.1080/09537287.2010.489276

Bardhi, F; Eckhardt, G. M. 2012. Access-based consumption: the case of car sharing, Journal of Consumer Research 39(4): 881-898. https://doi.org/10.1086/666376

Belk, R. 2014. You are what you can access: sharing and collaborative consumption online, Journal of Business Research 67(8): 1595-1600. https://doi.org/10.1016/j.jbusres.2013.10.001

Boyac1, B.; Zografos, K. G.; Geroliminis, N. 2015. An optimization framework for the development of efficient one-way carsharing systems, European Journal of Operational Research 240(3): 718-733. https://doi.org/10.1016/j.ejor.2014.07.020

Boyle, R. 1989. Partnership in practice - an assessment of public-private collaboration in urban regeneration - a case study of Glasgow action, Local Government Studies 15(2): 17-28. https://doi.org/10.1080/03003938908433460

Brandstätter, G.; Gambella, C.; Leitner, M.; Malaguti, E.; Masini, F., Puchinger, J.; Ruthmair, M.; Vigo, D. 2016. Overview of optimization problems in electric car-sharing system design and management, Dynamic Modeling and Econometrics in Economics and Finance 22: 441-471.

https://doi.org/10.1007/978-3-319-39120-5_24

Brooks, H.; Liebman, L.; Schelling, C. 1984. Public-Private Partnership: New Opportunities for Meeting Social Needs. Ballinger Publishing Company. 392 p.

Browne, M.; Nemoto, T.; Visser, J.; Whiteing, A. 2004. Urban Freight Movements and Public-Private Partnerships, in E. Taniguchi, R. G. Thompson (Eds.). Logistics Systems for Sustainable Cities, 17-35. https://doi.org/10.1108/9780080473222-002

Bubel, D.; Szymczyk, K. 2016. The smart freight project as a superior way to cope with congestion and environmental negative externalities in urban areas, Transportation Research Procedia 16: 25-34. https://doi.org/10.1016/j.trpro.2016.11.004

Bulkeley, H.; Schroeder, H.; Janda, K.; Zhao, J.; Armstrong, A.; Chu, S. Y.; Ghosh, S. 2011. The role of institutions, governance, and urban planning for mitigation and adaptation, in D. Hoornweg, M. Freire, M. J. Lee, P. Bhada-Tata, B. Yuen (Eds.). Cities and Climate Change: Responding to an Urgent Agenda, 125-159. https://doi.org/10.1596/9780821384930_CH05

Caggiani, L.; Ottomanelli, M. 2012. A modular soft computing based method for vehicles repositioning in bike-sharing systems, Procedia - Social and Behavioral Sciences 54: 675-684. https://doi.org/10.1016/j.sbspro.2012.09.785

Calvo, R. W.; De Luigi, F.; Haastrup, P.; Maniezzo, V. 2004. A distributed geographic information system for the daily car pooling problem, Computers \& Operations Research 31(13): 2263-2278. https://doi.org/10.1016/S0305-0548(03)00186-2

Cárdenas, I.; Beckers, J.; Vanelslander, T. 2017. E-commerce lastmile in Belgium: developing an external cost delivery index, Research in Transportation Business \& Management 24: 123129. https://doi.org/10.1016/j.rtbm.2017.07.006
Carley, M. 2000. Urban partnerships, governance and the regeneration of Britain's cities, International Planning Studies 5(3): 273-297. https://doi.org/10.1080/713672858

Carlsson-Kanyama, A.; Dreborg, K. H.; Moll, H. C.; Padovan, D. 2008. Participative backcasting: a tool for involving stakeholders in local sustainability planning, Futures 40(1): 34-46. https://doi.org/10.1016/j.futures.2007.06.001

Catalano, M.; Lo Casto, B.; Migliore, M. 2008. Car sharing demand estimation and urban transport demand modelling using stated preference techniques, European Transport $\backslash$ Trasporti Europei 40: 33-50.

Cervero, R. 2003. City CarShare: first-year travel demand impacts, Transportation Research Record: Journal of the Transportation Research Board 1839: 159-166.

https://doi.org/10.3141/1839-18

Chemla, D.; Meunier, F.; Calvo, R. W. 2013. Bike sharing systems: solving the static rebalancing problem, Discrete Optimization 10(2): 120-146. https://doi.org/10.1016/j.disopt.2012.11.005

Chen, L.; Zhang, D.; Pan, G.; Ma, X.; Yang, D.; Kushlev, K.; Zhang, W.; Li, S. 2015. Bike sharing station placement leveraging heterogeneous urban open data, in Proceedings of the 2015 ACM International Joint Conference on Pervasive and Ubiquitous Computing, 7-11 September 2015, Osaka, Japan, 571-575. https://doi.org/10.1145/2750858.2804291

Cherrett, T.; Allen, J.; McLeod, F.; Maynard, S.; Hickford, A.; Browne, M. 2012. Understanding urban freight activity - key issues for freight planning, Journal of Transport Geography 24: 22-32. https://doi.org/10.1016/j.jtrangeo.2012.05.008

Chung, D.; Hensher, D. A.; Rose, J. M. 2010. Toward the betterment of risk allocation: investigating risk perceptions of Australian stakeholder groups to public-private-partnership tollroad projects, Research in Transportation Economics 30(1): 43-58. https://doi.org/10.1016/j.retrec.2010.10.007

Crainic, T. G.; Laporte, G. 1997. Planning models for freight transportation, European Journal of Operational Research 97(3): 409-438. https://doi.org/10.1016/S0377-2217(96)00298-6

Davison, L. J.; Knowles, R. D. 2006. Bus quality partnerships, modal shift and traffic decongestion, Journal of Transport Geography 14(3): 177-194.

https://doi.org/10.1016/j.jtrangeo.2005.06.008

De Almeida Correia, G. H.; Antunes, A. P. 2012. Optimization approach to depot location and trip selection in one-way carsharing systems, Transportation Research Part E: Logistics and Transportation Review 48(1): 233-247.

https://doi.org/10.1016/j.tre.2011.06.003

De Jong, M.; Mu, R.; Stead, D.; Ma, Y.; Xi, B. 2010. Introducing public-private partnerships for metropolitan subways in China: what is the evidence?, Journal of Transport Geography 18(2): 301-313. https://doi.org/10.1016/j.jtrangeo.2009.06.013

De Langhe, K. 2017. The importance of external costs for assessing the potential of trams and trains for urban freight distribution, Research in Transportation Business \& Management 24: 114-122. https://doi.org/10.1016/j.rtbm.2017.07.002

DeMaio, P. 2009. Bike-sharing: history, impacts, models of provision, and future, Journal of Public Transportation 12(4): 41-56. https://doi.org/10.5038/2375-0901.12.4.3

Dimitrakopoulos, G.; Demestichas, P.; Koutra, V. 2012. Intelligent management functionality for improving transportation efficiency by means of the car pooling concept, IEEE Transactions on Intelligent Transportation Systems 13(2): 424-436. https://doi.org/10.1109/TITS.2011.2169669

Eitzen, H.; Lopez-Pires, F.; Baran, B.; Sandoya, F.; Chicaiza, J. L. 2017. A multi-objective two-echelon vehicle routing problem. An urban goods movement approach for smart city logistics, 
in 2017 XLIII Latin American Computer Conference (CLEI), 4-8 September 2017, Cordoba, Argentina, 1-10. https://doi.org/10.1109/CLEI.2017.8226454

Endicott, E. (Ed.). 1993. Land Conservation through Public/Private Partnerships. Island Press. 377 p.

Estrada, M.; Campos-Cacheda, J.-M.; Robusté, F. 2018. Night deliveries and carrier-led consolidation strategies to improve urban goods distribution, Transport 33(4): 930-947. https://doi.org/10.3846/transport.2018.6058

Expósito-Izquierdo, C.; Expósito-Márquez, A.; Brito-Santana, J. 2017. Mobility as a service, in H. Song, R. Srinivasan, T. Sookoor, S. Jeschke (Eds.). Smart Cities: Foundations, Principles, and Applications, 409-436.

Fan, W. (D).; Machemehl, R. B.; Lownes, N. E. 2008. Carsharing: dynamic decision-making problem for vehicle allocation, Transportation Research Record: Journal of the Transportation Research Board 2063: 97-104. https://doi.org/10.3141/2063-12

Faure, L.; Burlat, P.; Marquès, G. 2016. Evaluate the viability of urban consolidation centre with regards to urban morphology, Transportation Research Procedia 12: 348-356. https://doi.org/10.1016/j.trpro.2016.02.071

Fellows, N. T.; Pitfield, D. E. 2000. An economic and operational evaluation of urban car-sharing, Transportation Research Part D: Transport and Environment 5(1): 1-10. https://doi.org/10.1016/S1361-9209(99)00016-4

Ferrari, E.; Manzini, R.; Pareschi, A.; Persona, A.; Regattieri, A. 2003. The car pooling problem: heuristic algorithms based on savings functions, Journal of Advanced Transportation 37(3): 243-272. https://doi.org/10.1002/atr.5670370302

Ferreira, J.; Trigo, P.; Filipe, P. 2009. Collaborative car pooling system, International Journal of Social, Behavioral, Educational, Economic, Business and Industrial Engineering 3(6): 683-687.

Frade, I.; Ribeiro, A. 2015. Bike-sharing stations: a maximal covering location approach, Transportation Research Part A: Policy and Practice 82: 216-227.

https://doi.org/10.1016/j.tra.2015.09.014

Fricker, C.; Gast, N. 2016. Incentives and redistribution in homogeneous bike-sharing systems with stations of finite capacity, EURO Journal on Transportation and Logistics 5(3): 261-291. https://doi.org/10.1007/s13676-014-0053-5

Fricker, C.; Gast, N. Mohamed, H. 2012. Mean field analysis for inhomogeneous bike sharing systems, in DMTCS Proceedings Vol. AQ, 23rd Intern. Meeting on Probabilistic, Combinatorial, and Asymptotic Methods for the Analysis of Algorithms (AofA'12), 18-22 June 2012, Montreal, Canada, 1-12.

García-Palomares, J. C.; Gutiérrez, J.; Latorre, M. 2012. Optimizing the location of stations in bike-sharing programs: a GIS approach, Applied Geography 35(1-2): 235-246. https://doi.org/10.1016/j.apgeog.2012.07.002

Getz, D. 1986. Models in tourism planning: towards integration of theory and practice, Tourism Management 7(1): 21-32. https://doi.org/10.1016/0261-5177(86)90054-3

Gevaers, R.; Van de Voorde, E.; Vanelslander, T. 2011. Characteristics and typology of last-mile logistics from an innovation perspective in an urban context, in C. Macharis, S. Melo (Eds.). City Distribution and Urban Freight Transport: Multiple Perspectives, 56-72.

https://doi.org/10.4337/9780857932754.00009

Glaister, S. 1999. Past abuses and future uses of private finance and public private partnerships in transport, Public Money \& Management 19(3): 29-36.

https://doi.org/10.1111/1467-9302.00176
Goldman, T.; Gorham, R. 2006. Sustainable urban transport: four innovative directions, Technology in Society 28(1-2): 261-273. https://doi.org/10.1016/j.techsoc.2005.10.007

Golini, R.; Guerlain, C.; Lagorio, A.; Pinto, R. 2018. An assessment framework to support collective decision making on urban freight transport, Transport 33(4): 890-901.

https://doi.org/10.3846/transport.2018.6591

Gonzalez-Feliu, J. 2018. Sustainable Urban Logistics: Planning and Evaluation. Wiley-ISTE. 304 p. https://doi.org/10.1002/9781119421948

Gonzalez-Feliu, J.; Basck, P.; Morganti, E. 2013a. Urban logistics solutions and financing mechanisms: a scenario assessment analysis, European Transport \Trasporti Europei 54: 1-16.

Gonzalez-Feliu, J.; Goodchild, A.; Guerrero, D. 2016a. Datadriven innovations in policy-oriented freight transport models and planning methods, European Journal of Transport and Infrastructure Research 16(1): 1-3.

Gonzalez-Feliu, J.; Malhéné, N. 2014. Logistics pooling for city supply, Supply Chain Forum: an International Journal 15(4): 2-4. https://doi.org/10.1080/16258312.2014.11517362

Gonzalez-Feliu, J.; Malhéné, N.; Morganti, E.; Morana, J. 2014. The deployment of city and area distribution centers in France and Italy: comparison of six representative models, Supply Chain Forum: an International Journal 15(4): 84-99. https://doi.org/10.1080/16258312.2014.11517353

Gonzalez-Feliu, J.; Morana, J. 2010. Are city logistics solutions sustainable? The Cityporto case, TeMA: Journal of Land Use, Mobility and Environment 3(2): 55-64.

Gonzalez-Feliu, J.; Morana, J. 2014. Assessing urban logistics pooling sustainability via a hierarchic dashboard from a group decision perspective, in C. Macharis, S. Melo, J. Woxenius, T. Van Lier (Eds.). Transport and Sustainability. Vol. 6: Sustainable Logistics, 113-135.

https://doi.org/10.1108/S2044-994120140000006004

Gonzalez-Feliu, J.; Morana, J. 2011. Collaborative transportation sharing: from theory to practice via a case study from France, in J. Yearwood, A. Stranieri (Eds.). Technologies for Supporting Reasoning Communities and Collaborative Decision Making: Cooperative Approaches, 252-271.

https://doi.org/10.4018/978-1-60960-091-4.ch014

Gonzalez-Feliu, J.; Morana, J.; Salanova-Grau, J.-M.; Ma, T.-Y. 2013b. Design and scenario assessment for collaborative logistics and freight transport systems, International Journal of Transport Economics 40(2): 207-240.

Gonzalez-Feliu, J.; Salanova, J.-M. 2012. Defining and evaluating collaborative urban freight transportation systems, ProcediaSocial and Behavioral Sciences 39: 172-183.

https://doi.org/10.1016/j.sbspro.2012.03.099

Gonzalez-Feliu, J.; Salanova Grau, J.-M. 2015. Comparing fast VRP algorithms for collaborative urban freight transport systems: a solution probleming analysis, The IUP Journal of Supply Chain Management 12(2): 7-23.

Gonzalez-Feliu, J.; Semet, F.; Routhier, J.-L. 2016b. Sustainable Urban Logistics: Concepts, Methods and Information Systems Springer. 265 p. https://doi.org/10.1007/978-3-642-31788-0

Goodall, W.; Dovey, T.; Bornstein, J.; Bonthron, B. 2017. The rise of mobility as a service, Deloitte Review 20: 112-129.

Grimsey, D.; Lewis, M. K. 2002. Evaluating the risks of public private partnerships for infrastructure projects, International Journal of Project Management 20(2): 107-118. https://doi.org/10.1016/S0263-7863(00)00040-5

Grotenhuis, J.-W.; Wiegmans, B. W.; Rietveld, P. 2007. The desired quality of integrated multimodal travel information in 
public transport: customer needs for time and effort savings, Transport Policy 14(1): 27-38.

https://doi.org/10.1016/j.tranpol.2006.07.001

Hall, P. 2014. Cities of Tomorrow: an Intellectual History of Urban Planning and Design since 1880. Wiley-Blackwell. 640 p.

Haughton, G.; McManus, P. 2012. Neoliberal experiments with urban infrastructure: the cross city tunnel, Sydney, International Journal of Urban and Regional Research 36(1): 90-105. https://doi.org/10.1111/j.1468-2427.2011.01019.x

Hensher, D. A.; Button, K. J. 2007. Handbook of Transport Modelling. Emerald Publishing Ltd.

https://doi.org/10.1108/9780857245670

Hietanen, S. 2014. 'Mobility as a service' - the new transport model?, Eurotransport (2): 2-4.

Hine, J.; Mitchell, F. 2017. Transport Disadvantage and Social Exclusion: Exclusionary Mechanisms in Transport in Urban Scotland. Routledge. 168 p. https://doi.org/10.4324/9781315235677

Hull, A. 2005. Integrated transport planning in the UK: From concept to reality, Journal of Transport Geography 13(4): 318328. https://doi.org/10.1016/j.jtrangeo.2004.12.002

Jittrapirom, P.; Caiati, V.; Feneri, A.-M.; Ebrahimigharehbaghi, S.; Alonso-González, M. J.; Narayan, J. 2017. Mobility as a service: a critical review of definitions, assessments of schemes, and key challenges, Urban Planning 2(2): 13-25.

https://doi.org/10.17645/up.v2i2.931

Kamargianni, M.; Li, W.; Matyas, M.; Schäfer, A. 2016. A critical review of new mobility services for urban transport, Transportation Research Procedia 14: 3294-3303.

https://doi.org/10.1016/j.trpro.2016.05.277

Katzev, R. 2003. Car sharing: a new approach to urban transportation problems, Analyses of Social Issues and Public Policy 3(1): 65-86. https://doi.org/10.1111/j.1530-2415.2003.00015.x

Keeney, R. L. 2013. Foundations for group decision analysis, Decision Analysis 10(2): 103-120.

https://doi.org/10.1287/deca.2013.0265

Kek, A. G. H.; Cheu, R. L.; Meng, Q.; Fung, C. H. 2009. A decision support system for vehicle relocation operations in carsharing systems, Transportation Research Part E: Logistics and Transportation Review 45(1): 149-158.

https://doi.org/10.1016/j.tre.2008.02.008

Koppenjan, J. F. M. 2005. The formation of public-private partnerships: lessons from nine transport infrastructure projects in the Netherlands, Public Administration 83(1): 135-157. https://doi.org/10.1111/j.0033-3298.2005.00441.x

Koppenjan, J. F.; Enserink, B. 2009. Public-private partnerships in urban infrastructures: reconciling private sector participation and sustainability, Public Administration Review 69(2): 284-296. https://doi.org/10.1111/j.1540-6210.2008.01974.x

Lagorio, A.; Pinto, R.; Golini, R. 2015. Urban freight transport in an Italian mid-sized city: the Bergamo case from inception to stakeholders' involvement, in Proceeding of URBE (URban freight and BEhaviour change) Conference 2015, 1-2 October 2015, Roma, Italy.

Lambert, D. M.; Emmelhainz, M. A.; Gardner, J. T. 1999. Building successful logistics partnerships, Journal of Business Logistics 20(1): 165-181.

Lambert, D. M.; Knemeyer, A. M.; Gardner, J. T. 2004. Supply chain partnerships: model validation and implementation, Journal of Business Logistics 25(2): 21-42.

https://doi.org/10.1002/j.2158-1592.2004.tb00180.x

Lane, C. 2005. PhillyCarShare: first-year social and mobility impacts of carsharing in Philadelphia, Pennsylvania, Transportation Research Record: Journal of the Transportation Research Board 1927: 158-166.

https://doi.org/10.1177/0361198105192700118
Larsen, J. 2013. Bike-Sharing Programs Hit the Streets in Over 500 Cities Worldwide. Earth Policy Institute, Rutgers University, US. Available from Internet: http://www.earth-policy.org/ plan_b_updates/2013/update112

Li, J.-Q.; Zhou, K.; Zhang, L.; Zhang, W.-B. 2010. A multimodal trip planning system incorporating the park-and-ride mode and real-time traffic/transit information, in 17th ITS World Congress, Busan, 2010: Proceedings, 25-29 October 2010, Busan, South Korea.

Lindholm, M.; Browne, M. 2013. Local authority cooperation with urban freight stakeholders: a comparison of partnership approaches, European Journal of Transport and Infrastructure Research 13(1): 20-38.

Liu, Z.; Shiwakoti, N.; Bie, Y. 2018. Measuring the public acceptance of urban congestion-pricing: a survey in Melbourne (Australia), Transport 33(4): 902-912.

https://doi.org/10.3846/16484142.2016.1155170

Loukopoulos, P.; Scholz, R. W. 2004. Sustainable future urban mobility: using 'area development negotiations' for scenario assessment and participatory strategic planning, Environment and Planning A: Economy and Space 36(12): 2203-2226. https://doi.org/10.1068/a36292

Lue, C. C.; Crompton, J. L.; Fesenmaier, D. R. 1993. Conceptualization of multi-destination pleasure trips, Annals of Tourism Research 20(2): 289-301.

https://doi.org/10.1016/0160-7383(93)90056-9

Macharis, C.; Milan, L.; Verlinde, S. 2014. A stakeholder-based multicriteria evaluation framework for city distribution, $R e$ search in Transportation Business \& Management 11: 75-84. https://doi.org/10.1016/j.rtbm.2014.06.004

Maciejewski, M.; Bischoff, J. 2018. Congestion effects of autonomous taxi fleets, Transport 33(4): 971-980. https://doi.org/10.3846/16484142.2017.1347827

Maibach, M.; Schreyer, C.; Sutter, D.; Van Essen, H. P.; Boon, B. H.; Smokers, R.; Schroten, A.; Doll, C.; Pawlowska, B.; Bak, M. 2008. Handbook on Estimation of External Costs in the Transport Sector. Produced within the study Internalisation Measures and Policies for All external Cost of Transport (IMPACT). CE Delft, Netherlands. 336 p.

Marchau, V.; Walker, W.; Van Duin, R. 2008. An adaptive approach to implementing innovative urban transport solutions, Transport Policy 15(6): 405-412.

https://doi.org/10.1016/j.tranpol.2008.12.002

Martin, E. W.; Shaheen, S. A. 2011a. Greenhouse gas emission impacts of carsharing in North America, IEEE Transactions on Intelligent Transportation Systems 12(4): 1074-1086. https://doi.org/10.1109/TITS.2011.2158539

Martin, E.; Shaheen, S. 2011b. The impact of carsharing on public transit and non-motorized travel: an exploration of North American carsharing survey data, Energies 4(11): 2094-2114. https://doi.org/10.3390/en4112094

Martin, E.; Shaheen, S. A.; Lidicker, J. 2010. Impact of carsharing on household vehicle holdings: results from North American shared-use vehicle survey, Transportation Research Record: Journal of the Transportation Research Board 2143: 150-158. https://doi.org/10.3141/2143-19

Mason, R.; Lalwani, C.; Boughton, R. 2007. Combining vertical and horizontal collaboration for transport optimisation, Supply Chain Management: an International Journal 12(3): 187-199. https://doi.org/10.1108/13598540710742509

Mayeres, I.; Ochelen, S.; Proost, S. 1996. The marginal external costs of urban transport, Transportation Research Part D: Transport and Environment 1(2): 111-130. https://doi.org/10.1016/S1361-9209(96)00006-5 
Medda, F. 2007. A game theory approach for the allocation of risks in transport public private partnerships, International Journal of Project Management 25(3): 213-218.

https://doi.org/10.1016/j.ijproman.2006.06.003

Meijkamp, R. 1998. Changing consumer behaviour through eco-efficient services: an empirical study of car sharing in the Netherlands, Business Strategy and the Environment 7(4): 234-244.

https://doi.org/10.1002/(SICI)1099-0836(199809)7:4\%3C234 ::AID-BSE159\%3E3.0.CO;2-A

Melo, S.; Costa, A. 2011. Definition of a set of indicators to evaluate the performance of urban goods distribution initiatives, in C. Macharis, S. Melo (Eds.). City Distribution and Urban Freight Transport: Multiple Perspectives, 120-148. https://doi.org/10.4337/9780857932754.00013

Midgley, P. 2009. The role of smart bike-sharing systems in urban mobility, Journeys: Sharing Urban Transport Solutions 2(2): 23-31.

Millard-Ball, A.; Murray, G.; Schure, J; Fox, C.; Burkhardt, J. 2005. Car-Sharing: Where and How it Succeeds. Transit Cooperative Research Program (TRCP) Report 108. Transportation Research Board, Washington, DC, US. 255 p. https://doi.org/10.17226/13559

Mingrone, L.; Pignataro, G.; Roscia, M. 2015. Smart urban electric transport system: an innovative real model, in 2015 International Conference on Renewable Energy Research and Applications (ICRERA), 22-25 November 2015, Palermo, Italy, 1457-1462. https://doi.org/10.1109/ICRERA.2015.7418649

Morana, J.; Gonzalez-Feliu, J. 2015. A sustainable urban logistics dashboard from the perspective of a group of operational managers, Management Research Review 38(10): 1068-1085. https://doi.org/10.1108/MRR-11-2014-0260

Morana, J.; Gonzalez-Feliu, J.; Semet, F. 2014. Urban consolidation and logistics pooling: planning, management and scenario assessment issues, in J. Gonzalez-Feliu, F. Semet, J. L. Routhier (Eds.). Sustainable Urban Logistics: Concepts, Methods and Information Systems, 187-210.

https://doi.org/10.1007/978-3-642-31788-0_10

Muñoz-Villamizar, A.; Montoya-Torres, J. R.; Faulin, J. 2017. Impact of the use of electric vehicles in collaborative urban transport networks: a case study, Transportation Research Part D: Transport and Environment 50: 40-54. https://doi.org/10.1016/j.trd.2016.10.018

Muñoz-Villamizar, A.; Montoya-Torres, J. R.; Vega-Mejía, C. A. 2015. Non-collaborative versus collaborative last-mile delivery in urban systems with stochastic demands, Procedia CIRP 30: 263-268. https://doi.org/10.1016/j.procir.2015.02.147

Muñuzuri, J.; Escudero-Santana, A.; Aparicio-Ruiz, P. 2018. Under which conditions is carrier cooperation possible? A case study in a Seville marketplace, Transport 33(4): 881-889. https://doi.org/10.3846/transport.2018.6590

Nair, R.; Miller-Hooks, E.; Hampshire, R. C.; Bušić, A. 2013. Large-scale vehicle sharing systems: analysis of Vélib', International Journal of Sustainable Transportation 7(1): 85-106. https://doi.org/10.1080/15568318.2012.660115

Nimtrakool, K.; Gonzalez-Feliu, J.; Capo, C. 2018. Barriers to the adoption of an urban logistics collaboration process: a case study of the Saint-Etienne urban consolidation centre, in E. Taniguchi, R. G. Thompson (Eds.). City Logistics 2: Modeling and Planning Initiatives, 313-332. https://doi.org/10.1002/9781119425526.ch19

Ogden, K. W. 1991. Urban Goods Movement: a Guide to Policy and Planning. Ashgate Publishing Ltd.

Ortúzar, J. D.; Willumsen, L. G. 2011. Modelling Transport. Wiley. $607 \mathrm{p}$.
Osborne, S. 2002. Public-Private Partnerships: Theory and Practice in International Perspective. Routledge. 368 p. https://doi.org/10.4324/9780203207116

Paddeu, D.; Parkhurst, G.; Fancello, G.; Fadda, P.; Ricci, M. 2018. Multi-stakeholder collaboration in urban freight consolidation schemes: drivers and barriers to implementation, Transport 33(4): 913-929.

https://doi.org/10.3846/transport.2018.6593

Pan, S.; Ballot, E.; Fontane, F. 2013. The reduction of greenhouse gas emissions from freight transport by pooling supply chains, International Journal of Production Economics 143(1): 86-94. https://doi.org/10.1016/j.ijpe.2010.10.023

Piantanakulchai, M.; Saengkhao, N. 2003. Evaluation of alternatives in transportation planning using multi-stakeholders multi-objectives AHP modeling, Proceedings of the Eastern Asia Society for Transportation Studies 4: 1613-1628.

Pina, V;; Torres, L. 2006. Public-private efficiency in the delivery of services of general economic interest: The case of urban transport, Local Government Studies 32(2): 177-198. https://doi.org/10.1080/03003930600586167

Pohl, K. J. 2001. Perspective filters as a means for interoperability among information-centric decision-support systems, in Continuing the Revolution in Military Affairs (RMA), 5-7 June 2001, Quantico, VA, US, 125-130.

Potage, J. 1998. Les achats à Thomson-CSF: vers un nécessaire modèle de maturité, Revue Internationale de l'Achat 18(2): 11-18. (in French).

Potter, S.; Skinner, M. J. 2000. On transport integration: a contribution to better understanding, Futures 32(3-4): 275-287. https://doi.org/10.1016/S0016-3287(99)00097-X

Pronello, C.; Simão, J. P. R. V.; Rappazzo, V. 2017. The effects of the multimodal real time information systems on the travel behaviour, Transportation Research Procedia 25: 2677-2689. https://doi.org/10.1016/j.trpro.2017.05.172

Pronello, C.; Veiga-Simão, J.; Rappazzo, V. 2016. Can multimodal real-time information systems induce a more sustainable mobility?, Transportation Research Record: Journal of the Transportation Research Board 2566: 64-70. https://doi.org/10.3141/2566-07

Quinet, E.; Vickerman, R. 2004. Principles of Transport Economics. Edward Elgar Pub. 385 p.

Raiffa, H.; Richardson, J.; Metcalfe, D. 2007. Negotiation Analysis: the Science and Art of Collaborative Decision Making. Harvard University Press. 576 p.

Raviv, T.; Kolka, O. 2013. Optimal inventory management of a bike-sharing station, IIE Transactions 45(10): 1077-1093. https://doi.org/10.1080/0740817X.2013.770186

Raviv, T.; Tzur, M.; Forma, I. A. 2013. Static repositioning in a bike-sharing system: models and solution approaches, EURO Journal on Transportation and Logistics 2(3): 187-229. https://doi.org/10.1007/s13676-012-0017-6

Repoux, M.; Boyaci, B.; Geroliminis, N. 2015. Simulation and optimization of one-way car-sharing systems with variant relocation policies, in Transportation Research Board 94th Annual Meeting, 11-15 January 2015, Washington, DC, US, $1-19$.

Rickenberg, T. A. A.; Gebhardt, A.; Breitner, M. H. 2013. A decision support system for the optimization of car sharing stations, in Proceedings of the 21st European Conference on Information Systems (ECIS 2013), 6-8 June 2013, Utrecht, Netherlands, 1-12.

Roy, W.; Yvrande-Billon, A. 2007. Ownership, contractual practices and technical efficiency: the case of urban public transport in France, Journal of Transport Economics and Policy 41(2): 257-282. 
Sagner, J. S. 1974. The impact of the energy crisis on American cities based on dispersion of employment, utilization of transit, and car pooling, Transportation Research 8(4-5): 307-316. https://doi.org/10.1016/0041-1647(74)90049-5

Schuijbroek, J.; Hampshire, R. C.; Van Hoeve, W.-J. 2017. Inventory rebalancing and vehicle routing in bike sharing systems, European Journal of Operational Research 257(3): 992-1004. https://doi.org/10.1016/j.ejor.2016.08.029

Segalou, E.; Ambrosini, C.; Routhier, J.-L. 2004. The environmental assessment of urban goods movement, in E. Taniguchi, R. G. Thompson (Eds.). Logistics Systems for Sustainable Cities, 207-220. https://doi.org/10.1108/9780080473222-015

Shaheen, S. A.; Cohen, A. P. 2013. Carsharing and personal vehicle services: worldwide market developments and emerging trends, International Journal of Sustainable Transportation 7(1): 5-34. https://doi.org/10.1080/15568318.2012.660103

Shaheen, S. A.; Cohen, A. P.; Roberts, J. D. 2006. Carsharing in North America: market growth, current developments, and future potential, Transportation Research Record: Journal of the Transportation Research Board 1986: 116-124.

https://doi.org/10.1177/0361198106198600115

Shaheen, S. A.; Schwartz, A.; Wipyewski, K. 2004. Policy considerations for carsharing and station cars: monitoring growth, trends, and overall impacts, Transportation Research Record: Journal of the Transportation Research Board 1887: 128-136. https://doi.org/10.3141/1887-15

Shaheen, S.; Sperling, D.; Wagner, C. 1998. Carsharing in Europe and North America: past, present, and future, Transportation Quarterly 52(3): 35-52.

Simonot, P.-Y., Roure, J. 2007. Logistique collaborative: Une question d'avenir. Paris: Economica. 260 p. (in French).

Sochor, J.; Strömberg, H.; Karlsson, I. C. M. 2015. Implementing mobility as a service: challenges in integrating user, commercial, and societal perspectives, Transportation Research Record: Journal of the Transportation Research Board 2536: 1-9. https://doi.org/10.3141/2536-01

Spickermann, A.; Grienitz, V.; Von der Gracht, H. A. 2014. Heading towards a multimodal city of the future?: Multistakeholder scenarios for urban mobility, Technological Forecasting and Social Change 89: 201-221.

https://doi.org/10.1016/j.techfore.2013.08.036

Stathopoulos, A.; Valeri, E.; Marcucci, E. 2012. Stakeholder reactions to urban freight policy innovation, Journal of Transport Geography 22: 34-45.

https://doi.org/10.1016/j.jtrangeo.2011.11.017

Steininger, K.; Vogl, C.; Zettl, R. 1996. Car-sharing organizations: The size of the market segment and revealed change in mobility behavior, Transport Policy 3(4): 177-185.

https://doi.org/10.1016/S0967-070X(96)00024-8

SUGAR. 2011. City Logistics Best Practices: a Handbook for Authorities. Sustainable Urban Goods Logistics Achieved by Regional and Local Policies (SUGAR). 276 p. Available from Internet: http://www.sugarlogistics.eu/pliki/handbook.pdf

Tang, Y.; Pan, H.; Shen, Q. 2011. Bike-sharing systems in Beijing, shanghai, and Hangzhou and their impact on travel behavior, in Transportation Research Board 90th Annual Meeting, 23-27 January 2011, Washington, DC, US, 1-12.

Taniguchi, E.; Thompson, R. G. 2014. City Logistics: Mapping the Future. CRC Press. 231 p.

Tettamanti, T.; Csikós, A.; Kis, K. B.; Viharos, Z. J.; Varga, I. 2018. Pattern recognition based speed forecasting methodology for urban traffic network, Transport 33(4): 959-970.

https://doi.org/10.3846/16484142.2017.1352027

Thompson, R. G.; Hassall, K. P. 2012. A collaborative urban dis- tribution network, Procedia - Social and Behavioral Sciences 39: 230-240. https://doi.org/10.1016/j.sbspro.2012.03.104

Tight, M.; Timms, P.; Banister, D.; Bowmaker, J.; Copas, J.; Day, A.; Drinkwater, D.; Givoni, M.; Gühnemann, A.; Lawler, M.; Macmillen, J.; Miles, A.; Moore, N.; Newton, R.; Ngoduy, D.; Ormerod, M.; O’Sullivan, M.; Watling, D. 2011. Visions for a walking and cycling focussed urban transport system, Journal of Transport Geography 19(6): 1580-1589. https://doi.org/10.1016/j.jtrangeo.2011.03.011

Tran, T. D.; Ovtracht, N.; D’Arcier, B. F. 2015. Modeling bike sharing system using built environment factors, Procedia CIRP 30: 293-298. https://doi.org/10.1016/j.procir.2015.02.156

Trasarti, R.; Pinelli, F.; Nanni, M.; Giannotti, F. 2012. Mining mobility user profiles for car pooling, in KDD'11: Proceedings of the 17th ACM SIGKDD Conference on Knowledge Discovery and Data Mining, 21-24 August 2011, San Diego, CA, US, 1190-1198. https://doi.org/10.1145/2020408.2020591

Trentini, A.; Mahléné, N. 2010. Toward a shared urban transport system ensuring passengers \& goods cohabitation, TeMA: Journal of Land Use, Mobility and Environment 3(2): 37-44.

Urry, J. 2016. Mobilities: New Perspectives on Transport and Society. Routledge. 348 p. https://doi.org/10.4324/9781315595733

Vaghi, C.; Percoco, M. 2011. City logistics in Italy: success factors and environmental performance, in C. Macharis, S. Melo (Eds.). City Distribution and Urban Freight Transport: Multiple Perspectives, 151-175.

https://doi.org/10.4337/9780857932754.00015

Van Duin, R.; Slabbekoorn, M.; Tavasszy, L.; Quak, H. 2018. Identifying dominant stakeholder perspectives on urban freight policies: a $Q$-analysis on urban consolidation centres in the Netherlands, Transport 33(4): 867-880.

https://doi.org/10.3846/16484142.2017.1350996

Van Wee, B. 2016. Accessible accessibility research challenges, Journal of Transport Geography 51: 9-16.

https://doi.org/10.1016/j.jtrangeo.2015.10.018

Veličković, M.; Stojanović, Đ.; Nikoličić, S.; Maslarić, M. 2018. Different urban consolidation centre scenarios: impact on external costs of last-mile deliveries, Transport 33(4): 948-958. https://doi.org/10.3846/16484142.2017.1350995

Verhoef, E. 1994. External effects and social costs of road transport, Transportation Research Part A: Policy and Practice 28(4): 273-287. https://doi.org/10.1016/0965-8564(94)90003-5

Verlinde, S.; Macharis, C.; Witlox, F. 2012. How to consolidate urban flows of goods without setting up an urban consolidation centre?, Procedia - Social and Behavioral Sciences 39: 687-701. https://doi.org/10.1016/j.sbspro.2012.03.140

Vickrey, W. S. 1963. Pricing in urban and suburban transport, The American Economic Review 53(2): 452-465.

Vogel, P.; Greiser, T.; Mattfeld, D. C. 2011. Understanding bikesharing systems using data mining: exploring activity patterns, Procedia - Social and Behavioral Sciences 20: 514-523. https://doi.org/10.1016/j.sbspro.2011.08.058

Willoughby, C. 2013. How much can public private partnership really do for urban transport in developing countries?, Research in Transportation Economics 40(1): 34-55. https://doi.org/10.1016/j.retrec.2012.06.038

Yan, S.; Chen, C.-Y.; Lin, Y.-F. 2011. A model with a heuristic algorithm for solving the long-term many-to-many car pooling problem, IEEE Transactions on Intelligent Transportation Systems 12(4): 1362-1373.

https://doi.org/10.1109/TITS.2011.2158209

Yescombe, E. R.; Farquharson, E. 2018. Public-Private Partnerships for Infrastructure: Principles of Policy and Finance. Butterworth-Heinemann. 508 p. 